\title{
EXPERIENCE IN CHILDREN IN THE COVID-19 PANDEMIC OF A TERTIARY CENTER, IN ISTANBUL
}

\author{
ISTANBUL'DA ÜCCÜNCÜ BASAMAK BIR MERKEZIN COVID-19 PANDEMISINDE \\ ÇOCUKLARDAKI DENEYIMI
}

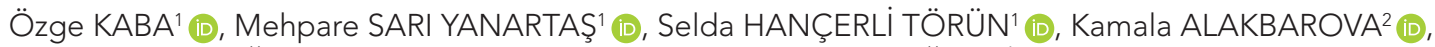 \\ Zuhal BAYRAMOĞLU iD, Mustafa ÖNEL ${ }^{4}$ iD, Sevim Meşe ${ }^{4}$ (D), Ali AĞAÇFiDAN ${ }^{4}$ (D), Ayper SOMER ${ }^{1}$ (D) \\ ${ }^{1}$ Istanbul University, Istanbul Faculty of Medicine, Department of Pediatrics, Division of Pediatric Infectious Disease, Istanbul, Turkey \\ ${ }^{2}$ Istanbul University, Istanbul Faculty of Medicine, Department of Pediatrics, Istanbul, Turkey \\ ${ }^{3}$ Istanbul University, Istanbul Faculty of Medicine, Department of Radiology, Division of Pediatric Radiology, Istanbul, Turkey \\ ${ }^{4}$ Istanbul University, Istanbul Faculty of Medicine, Department of Microbiology, Istanbul, Turkey
}

ORCID IDs of the authors: Ö.K. 0000-0002-8381-3255; M.S.Y. 0000-0002-7035-6673; S.H.T. 0000-0002-3216-2413;

K.A. 0000-0001-8942-9986; Z.B. 0000-0002-1695-3290; M.Ö. 0000-0002-3987-6611; S.M. 0000-0001-5944-0180;

A.A. 0000-0002-5470-296X; A.S. 0000-0002-7827-1113

Cite this article as: Kaba O, Sari Yanartas M, Hancerli Torun S, Alakbarova K, Bayramoglu Z, Onel M, et al. Experience in children in the COVID-19 pandemic of a tertiary center, in Istanbul. J Ist Faculty Med 2021;84(3):293-300. doi: 10.26650/IUITFD.2021.806433

\section{ABSTRACT}

Objective: The SARS-CoV-2 virus, which unexpectedly has affected the whole world, continues to infect millions of people and causes the death of hundreds of thousands of people. There has been no consensus on the pediatric age group yet. For this reason, it was aimed to share the pediatric group experience of our center.

Material and Method: After the pandemic announcement, 1076 pediatric cases admitted to our center with suspected COVID-19 disease were discussed. Eighty-five children who were positive in the SARS-CoV-2 polymerase chain reaction test, were evaluated retrospectively with epidemiological, clinical, laboratory and imaging data.

Results: Half of the patients were male and about half of them were between 60-179 months. The household contact/exposure was $80 \%$ of the patients. The most common complaints were cough and fever, with the rates of $51.8 \%$ and $47.1 \%$, respectively. There was a milder clinic $72.9 \%$ of patients and critical illness only $2.4 \%$ of the patients. The most striking laboratory finding was lymphopenia. Imaging results showed that abnormal thorax CT rate was $10.6 \%$. Isolation at home was administered on $80 \%$ of the patients. Various specific treatments were used only in $4.7 \%$ of the hospitalized patients. One of these patients who received hydroxychloroquine, intravenous immunglobuline and tocilizumab died. The mortality rate was $1.5 \%$.

Conclusion: In the absence of reliable diagnostic tests and specific antiviral treatments appropriate for children, it was conclu-

\section{ÖZET}

Amaç: Beklenmedik bir anda tüm dünyayı etkileyen SARS-CoV-2 virüsü milyonlarca insanı enfekte etmeye ve yüzbinlerce insanın da ölüme neden olmaya devam etmektedir. Pediyatrik yaş grubuna dair görüş birliği henüz sağlanamamıştır. Bu nedenle merkezimize ait pediyatrik grup deneyiminin paylaşılması amaçlanmıştır.

Gereç ve Yöntem: Pandemi ilanından sonra merkezimize COVID-19 hastalığı şüphesiyle başvuran 1076 çocuk olgu ele alındı. SARS-CoV-2 polimeraz zincir reaksiyon testinde pozitif olan 85 çocuk, epidemiyolojik, klinik, laboratuvar ve görüntüleme verileri ile retrospektif olarak değerlendirildi.

Bulgular: Hastaların yarısı erkek ve yaklaşık yarısı 60-179 ay arasındaydı. Hastaların \%80'inde ev içi temas/maruziyet mevcuttu. En sık şikayetler sırasıyla \%51,8 ve \%47,1 oranlarıyla öksürük ve ateşti. Hastaların \%72,9'unda daha hafif klinik tablo ve sadece $\% 2,4$ 'ünde kritik hastalık vardı. En çarpıcı laboratuvar bulgusu lenfopeniydi. Görüntüleme sonuçları, anormal toraks BT oranının \%10,6 olduğunu gösterdi. Hastaların \%80'ine evde izolasyon uygulandı. Hastanede yatan hastaların sadece $\% 4,7$ 'sinde çeşitli spesifik tedaviler uygulandı. Hidroksiklorokin, intravenöz immünglobulin ve tosilizumab alan bu hastalardan biri öldü. Mortalite oranı \%1,5 idi.

Sonuç: Güvenilir tanısal testlerin ve çocuklar için uygun spesifik antiviral tedavilerin yokluğunda, COVID-19 enfeksiyonunu daha

Corresponding author/iletişim kurulacak yazar: ozgekabamd@gmail.com

Submitted/Başvuru: 06.10.2020 • Revision Requested/Revizyon Talebi: 15.03.2021 •

Last Revision Received/Son Revizyon: 23.03.2021 • Accepted/Kabul: 09.04.2021 • Published Online/Online Yayın: 29.06 .2021 
ded that we need more virological, epidemiological, clinical, laboratory and imaging studies to better understand and manage COVID-19 infection.

Keywords: COVID-19, child, management, treatment iyi anlamak ve yönetmek için daha virolojik, epidemiyolojik, klinik, laboratuvar ve görüntüleme çalışmalarına ihtiyaç olduğu fikrine varıldı.

Anahtar Kelimeler: COVID-19, çocuk, yönetim, tedavi

\section{INTRODUCTION}

The severe acute respiratory syndrome coronavirus 2 (SARS-CoV-2) virus, which appeared in China in December 2019, spread rapidly and was declared as a pandemic by the World Health Organization (WHO) on March 11, 2020 (1). The virus, which has been seen in 235 countries to date, has caused $34,804,348$ people to become infected and 1,030,738 people to die (2). It is manifested by symptoms such as fever, dry cough, and dyspnea in the adult age group, leading to serious diseases, especially pneumonia (3). Articles published to date show that the COVID-19 disease is milder in childhood (4). In addition, there are small case series and case reports that include quite different approaches with treatment procedures, and management and treatment is also continuing. Based on this, it is aimed to present the data of the pediatric patients who followed-up in our center.

\section{MATERIAL AND METHOD}

As of the announcement of the first case in our country, in accordance with the pandemic preparations at our facility, a service area where possible cases are evaluated in terms of COVID-19 disease and a service area where suspicious patients can be monitored has been organized. One-thousand-seventy-six children between 1 and 216 months who were admitted to our hospital between the dates of 11 March, 2020 and 1 June, 2020 and who conformed to the possible case definition in accordance with the Ministry of Health COVID-19 (SARS-CoV-2 infection) guideline were evaluated by pediatric infectious disease specialists (5). Epidemiological, demographic, laboratory, imaging, treatment and follow-up data of 85 patients, whose SARSCoV-2 polymerase chain reaction (PCR) was positive in the combined nasal and nasopharyngeal swab samples taken were obtained by examining the files retrospectively. Patients less than a month were not included in the study.

Patients were divided into 5 categories according to clinical data. These categories are listed below (6). 1) Asymptomatic infection: Normal imaging features and nucleic acid test positivity without symptoms. 2) Mild disease: Acute upper respiratory infection with symptoms like fever, sore throat, cough and/or myalgia. 3) Moderate disease: Pneumonia, which does not require oxygen, manifested by symptoms such as fever and cough (mostly dry). 4) Severe disease: Pneumonia, which requires oxygen, manifested by symptoms such as fever and cough and signs of hypoxia. 5) Critical disease: Respiratory failure requiring mechanical ventilation, acute respiratory distress syndrome (ARDS), shock, and multiple organ failure. In addition, cases similar to Kawasaki syndrome were reported in many countries, firstly in England, in April 2020, and it was named as multisystemic inflammatory syndrome in children (MIS-C). In accordance with the symptoms, imaging results such as direct radiography or thorax computer tomography (CT) applied to children were re-evaluated together with the pediatric radiology specialist.

Molecular tests of pediatric patients with suspected COVID-19 disease were studied in the COVID-19 Laboratory authorized by the Ministry of Health, within the Department of Virology and Basic Immunology of our hospital. Combined nasal and nasopharyngeal swab samples taken from patients were sent in viral transport medium (VTM) together with patient information forms in accordance with cold chain rules with triple transport system.

In our laboratory, viral nucleic acid isolation kit (Biospeedy, Catno: BS-NA-109-1000) and reverse transcriptase (RT), real-time (q) PCR kit (Biospeedy, BS-SY-WCOR-305-1000) available from the Ministry of Health is used for the molecular diagnosis of COVID-19. Viral nucleic acid isolation process is run manually in the BSL-2 cabinet. RT-qPCR is performed on the Rotor Gene Q (QIAGEN, Germany) device. In the RT-qPCR kit, RNA-dependent RNA polymerase $(R d R p)$ gene region is targeted specifically for SARS-CoV-2. In the working principle of this kit, the human ribonuclease $\mathrm{P}$ gene is used as internal control. The positivity of RNAse $\mathrm{P}$ for the PCR procedure indicates that the test is working correctly. By determining the amplification curves of the RdRP gene region, COVID-19 positive result is obtained.

The collected data were studied in the 23.0 version of the SPSS programme using descriptive statistical methods, and values were expressed as percentage, mean, and standard deviation. It was planned to compare the asymptomatic patient group and the symptomatic patient group with the non-parametric tests using the chi-square test and, if necessary, to support Fisher's Exact test. Data without normal distribution of two independent groups were evaluated by Mann-Whitney $U$ test.

Since it was a retrospective study based on file scanning, the informed consent form was not needed. Approval was received for the application numbered 2020-0511T13_00_56 to the scientific committee of the Ministry of Health. Approval was also obtained from our hospital's ethics committee (Date: 15.05.2020, No: 10). 


\section{RESULTS}

One-thousand-seventy-six of the patients who applied to the pandemic areas established in our institution to combat the COVID-19 disease were evaluated in accordance with the COVID-19 (SARS-CoV-2 infection) guideline prepared by the Ministry of Health. SARS-CoV-2 was detected in 85 patients' swab samples. Male gender of the patients with the diagnosis of the COVID-19 disease was $49.4 \%$. The average age of the patients included in the study was $119.01 \pm 61.82$ (range 4-204) months. Detailed data regarding the demographic and epidemiological in- formation of the patients are presented in Table 1. These data were also compared between the asymptomatic and symptomatic groups, but no significant value was found.

Comorbid diseases in our patients were reactive airway disease, malignancy, cerebral palsy, Hashimoto thyroiditis, hypertension, newly diagnosed diabetes mellitus, carboxylase deficiency, cyclic neutropenia and De-Barsy syndrome $(1,2,3)$.

Considering the complaints, $51.8 \%$ cough, $47.1 \%$ fever, $18.8 \%$ myalgia and $12.9 \%$ sore throat were present.

Table 1: Demographic and epidemiological data distribution of patients with SARS-CoV-2 ${ }^{\ddagger}$

\begin{tabular}{|c|c|c|c|c|}
\hline & \multicolumn{4}{|c|}{ n (\%) } \\
\hline & Total & Asymptomatic & Symptomatic & $p$ value \\
\hline Gender & & & & 0.745 \\
\hline Male & $42(49.4)$ & $9(10.6)$ & $33(38.8)$ & \\
\hline Female & $43(50.6)$ & $8(9.4)$ & $35(41.2)$ & \\
\hline Age group ranges & & & & $0.176^{\star \star}$ \\
\hline $1-11$ months & $3(3.5)$ & $2(2.4)$ & $1(1.2)$ & \\
\hline $12-59$ months & $17(20.0)$ & $2(2.4)$ & $15(17.6)$ & \\
\hline $60-179$ months & $39(42.4)$ & $9(10.6)$ & $30(35.3)$ & \\
\hline 180 months and over & $26(30.6)$ & $4(4.7)$ & $22(25.9)$ & \\
\hline Presence of exposure/contact & $68(80)$ & $15(17.6)$ & $53(62.4)$ & $0.504^{\star \star}$ \\
\hline Number of individuals with exposure/contact & & & & $0.000^{* \star}$ \\
\hline One & $50(58.8)$ & $11(13.0)$ & $39(45.9)$ & \\
\hline Two & $11(13.0)$ & $3(3.5)$ & $8(9.4)$ & \\
\hline Three and over & $7(8.3)$ & $0(0.0)$ & $7(8.3)$ & \\
\hline Presence of comorbidity & $12(14.1)$ & $2(2.4)$ & $10(11.8)$ & $1.000^{\star \star}$ \\
\hline Clinical case status & & & & $0.000^{* *}$ \\
\hline Asymptomatic & $17(20.0)$ & $17(20.0)$ & $0(0.0)$ & \\
\hline Mild disease & $62(72.9)$ & $0(0.0)$ & $62(72.9)$ & \\
\hline Moderate disease & $3(3.5)$ & $0(0.0)$ & $3(3.5)$ & \\
\hline Severe disease & $1(1.2)$ & $0(0.0)$ & $1(1.2)$ & \\
\hline Critical disease & $2(2.4)$ & $0(0.0)$ & $2(2.4)$ & \\
\hline Follow-up decision & & & & $0.738^{\star \star}$ \\
\hline At home & $68(80.0)$ & $13(15.2)$ & $55(64.7)$ & \\
\hline At hospital & $17(20.0)$ & $4(4.8)$ & $13(15.2)$ & \\
\hline Follow-up with specific treatment & $5(5.8)$ & $0(0.0)$ & $5(5.8)$ & $0.578^{\star \star}$ \\
\hline Outcome & & & & $0.265^{\star \star}$ \\
\hline Discharge & $16(18.8)$ & $3(3.5)$ & $13(15.2)$ & \\
\hline Complication & $0(0.0)$ & $0(0.0)$ & $0(0.0)$ & \\
\hline Mortality & $1(1.2)$ & $0(0.0)$ & $1(1.2)$ & \\
\hline
\end{tabular}

N: Number of cases. ${ }^{*}$ chi-square test, ${ }^{* \star}$ Fisher's Exact Test; ${ }^{\ddagger}$ Percentages may not total 100 because of rounding 
The symptoms of runny nose, diarrhea and shortness of breath observed in the application were also evaluated. The mean duration of symptoms, clinical disease groups and follow-up decision in patients with symptoms are presented in Table 2. In addition, 7 (8.2\%) of the patients who suggested respiratory tract infection with the current symptoms had a swab sample to detect other viral respiratory viruses, but any viruses could be detected.

The most striking finding was the presence of lymphopenia in 32 patients. In addition, leukocytosis in nine patients, leukopenia in nine patients, thrombocytopenia in seven patients, neutropenia in eight patients were among the abnormal blood counts. There were slightly increased C-reactive protein, D-dimer and liver function tests. The increase of procalcitonin has been detected only in three patients. The evaluations of the patients for their laboratory and imaging are presented in Table 3. Laboratory investigations and imaging results were evaluated, and $80 \%$ of the patients were isolated at home.
After the first evaluation 33 (38.8\%) of patients were imagined with low dose thorax CT because of reasons such as abnormal graphy, comorbidity. Parenchymal findings compatible with COVID-19 were present in nine of the symptomatic patients. Only 11 patients had an abnormal chest $X$-ray. In none of these patient groups, recurrent thorax CT

Table 2: Data distribution of the symptoms and clinical disease status of the patients evaluated after the admission

\begin{tabular}{lcc}
\hline Symptoms & $\begin{array}{c}\text { Number of cases } \\
\text { (\% value) }\end{array}$ & $\begin{array}{c}\text { Duration of } \\
\text { symptoms (day) } \\
\text { (mean } \pm \text { SD) }\end{array}$ \\
\hline Cough & $44(51.8)$ & $2.34 \pm 1.68$ \\
Fever & $40(47.1)$ & $1.80 \pm 1.12$ \\
Myalgia & $16(18.8)$ & $2.31 \pm 1.40$ \\
Sore throat & $11(12.9)$ & $1.82 \pm 0.98$ \\
Dyspnea & $6(7.1)$ & $2.17 \pm 1.60$ \\
Diarrhea & $5(5.9)$ & $2.20 \pm 0.83$ \\
Runny nose & $5(5.9)$ & $2.00 \pm 1.22$ \\
\hline
\end{tabular}

Table 3: Comparison of laboratory and imaging parameters by patient groups ${ }^{\ddagger}$

\begin{tabular}{|c|c|c|c|c|}
\hline & \multicolumn{4}{|c|}{$n(\%)$} \\
\hline & Total & Asymptomatic & Symptomatic & $p$ value \\
\hline WBC count & & & & $0.576^{\star \star}$ \\
\hline Leukocytosis & $9(10.6)$ & $3(3.5)$ & $6(7.1)$ & \\
\hline Leukopenia & $9(10.6)$ & $1(1.2)$ & $8(9.4)$ & \\
\hline Neutropenia & $8(9.4)$ & $3(3.5)$ & $5(5.9)$ & $0.620^{\star \star}$ \\
\hline Lymphopenia & $32(37.6)$ & $7(8.2)$ & $25(29.4)$ & $0.421^{* \star}$ \\
\hline Thrombocytopenia & $7(8.2)$ & $1(1.2)$ & $6(7.1)$ & $1.000^{\star *}$ \\
\hline Increased C-reactive protein & $24(28.2)$ & $4(4.7)$ & $20(23.5)$ & $0.768^{\star \star}$ \\
\hline Increased procalcitonin & $3(3.5)$ & $0(0.0)$ & $3(3.5)$ & $1.000^{* *}$ \\
\hline Increased alanine transaminase & $5(5.9)$ & $1(1.2)$ & $4(4.7)$ & $1.000^{* \star}$ \\
\hline Increased aspartate transaminase & $14(16.4)$ & $3(3.5)$ & $11(13.0)$ & $1.000^{* *}$ \\
\hline Increased lactate dehydrogenase & $6(7.1)$ & $0(0.0)$ & $6(7.1)$ & $0.342^{* \star}$ \\
\hline Increased D-dimer & $16(18.8)$ & $5(5.9)$ & $11(13.0)$ & $0.296^{* \star}$ \\
\hline Increased troponin & $4(4.7)$ & $0(0.0)$ & $4(4.7)$ & $0.579 * \star$ \\
\hline \multicolumn{5}{|l|}{ Imaging } \\
\hline Direct graphy & & & & $0.526^{* *}$ \\
\hline $\begin{array}{l}\text { Normal } \\
\text { Anormal }\end{array}$ & $\begin{array}{l}68(80.0) \\
11(13.0)\end{array}$ & $\begin{array}{c}14(16.4) \\
1(1.2)\end{array}$ & $\begin{array}{l}54(63.6) \\
10(11.8)\end{array}$ & \\
\hline Thorax CT & & & & $0.256^{* *}$ \\
\hline Normal & $24(28.2)$ & $4(4.7)$ & $20(23.6)$ & \\
\hline Appropriate with COVID-19 disease & $9(10.6)$ & $0(0.0)$ & $9(10.6)$ & \\
\hline
\end{tabular}

$\mathrm{N}$, number of cases; WBC, white blood cell; NA, non-available; CT, computer tomography; ${ }^{\ddagger}$ Percentages may not total 100 because of rounding; ${ }^{*}$ chi-square test, ${ }^{\star \star}$ Fisher's Exact Test 


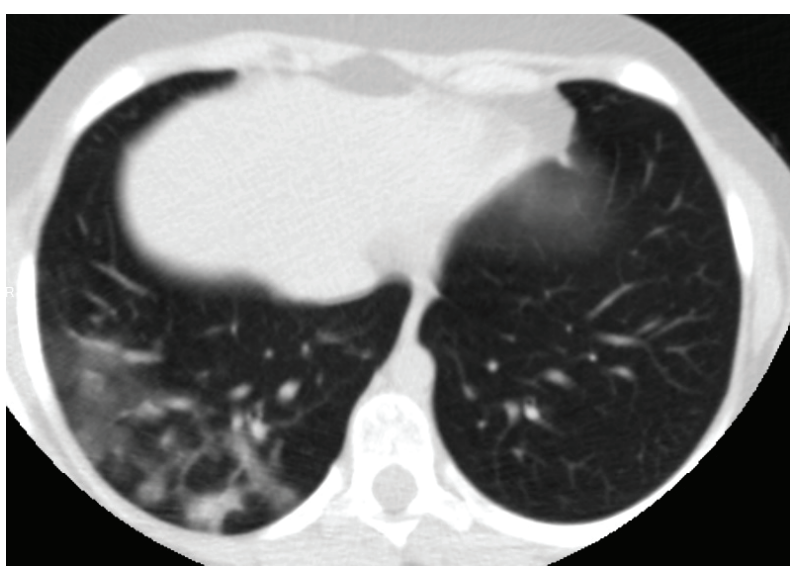

Figure 1a: Chest CT images of children with COVID-19 axial section. Peribrochial involvement of right lower lobe with ground glass opacity and accompanying consolidation in a 10 years old male patient

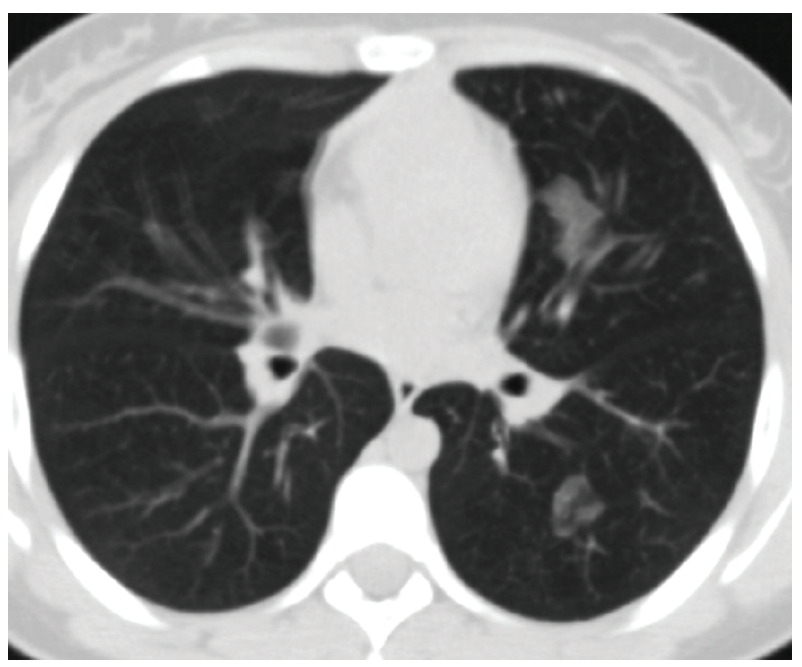

Figure 1b: Chest CT images of children with COVID-19 axial section. Patchy ground glass infiltrations in the left upper and lower lobe in a 15 year old female patient

imaging was required. The most common findings in our patient group were glass ground opacities. Images of two of our patients can be seen in Figure 1a and 1b.

In symptomatic patients hydroxychloroquine treatment with ratio $3.5 \%(n=3)$ was preferred at the beginning of the pandemic. One of these patients had a diagnosed malignancy, one had multisystemic inflammatory syndrome, and the other had poor adult-type thorax CT findings. Tocilizumab was also administered to the patient with critical illness who was taking hydroxychloroquine. Plasmapheresis was applied together with favipravir treatment in another critically ill patient who was admitted in the later period of the pandemic. Except for these four patients, all patients were followed up with symptomatic treatment. No side effects or complications were observed during the treatment process. After the treatment, all patients were discharged except one. One of the patients with critical disease who applied on the $4^{\text {th }}$ day of the symptoms and administered tocilizumab, intravenous immunglobuline and hydroxychloroquine died because of multisystemic inflammatory syndrome.

\section{DISCUSSION}

SARS-CoV-2 is an emerging pathogen causing upper respiratory system infection and pneumonia all over the world. At the pediatric age group, it is known that the number of cases is less than the adult age group, the clinical course is less severe, and the mortality is lower. When only the pediatric patients who applied to our institution and the patients with epidemiological data, fever and respiratory symptoms were evaluated, the positivity ratio was found $7.89 \%$. This rate, which was determined as $12 \%$ with the evaluation of 1391 children in Wuhan, was lower in our study (7). Considering the date of our country, including adult patients, the rate of pediatric cases have been determined to be $1 \%$ as of the end of March 2020 (8). However, this rate was similar to Italy with the rate of $1 \%$, Spain with the rate of $0.8 \%(9,10)$. At the onset of the pandemic, the rate of children reported as $1.7 \%$ in the United States increased to $4 \%$ for the $0-9$ age group, and $11.5 \%$ for the 10-19 age group in August (11). In the study, in which 72,314 cases were evaluated in China, cases belonging to the pediatric group were reported at the rate of approximately $2.2 \%$ (12). Fifty percent of male gender ratio contrasted with the predominance of female gender data from the studies of Parri et al. and Tagarro et al. $(9,10)$. In the publication of Lue et al which 171 patients were evaluated, this rate increased to $60.8 \%$ (8). The mean age of the patients included in the study was 119.01 months, which was approximately 9.8 years compatible with our country data (8). In the age distribution data of the studied patients, it was observed that the 60-179 months group was the first with $45.9 \%$, and the group of 180 months and over was the second with $30.6 \%$. When the studies involving a large number of patients were examined, it was seen that the case density was clustered especially at the age of six years and over like our study (9).

The coronavirus epidemic, which appeared later in our country compared to Asian and European countries, had a serious effect on the public's decision to travel. Of our positive cases, only three patients belonging to the same family had a travel history. After the first case was seen on the $11^{\text {th }}$ of March, 2020 in our country, the schools were closed just a day later in order to prevent the child age group, thought to be a super carrier, to spread the disease (13). That situation resulted in a household contact rate, similar to Centers for Disease Control (CDC) data, as seen in our data. Considering the number of individuals exposed to pre-infection, an individual contact was $60 \%$, and as the number of individuals increased, this rate was 
expressed in numbers, suggesting the isolation success provided within the home. When we look at the number of contact individuals discussed in the study by Zhang et al. contrary to our study, it was observed that as the number of individuals increased, the rate of exposure increased correspondingly (14).

Considering positive cases with PCR test results that were evaluated as possible cases, 12 patients had comorbid disease. The new diagnosis of diabetes in one of these patients, malignancy in two, and the presence of hypertension in one coincided with the risk factors of the adult age group (15). Although four patients with comorbidity were asymptomatic, they were hospitalized and followed-up. Immunosuppression, chronic lung diseases and cardiovascular diseases have been identified as risk factors that worsen the disease, and all risk factors are still uncertain (16).

The most common symptoms detected in our patients included in the study were cough and fever symptoms with $51.8 \%$ and $47.1 \%$. These rates were in line with the 100 case studies published by Parri et al. and the 2.572 case study published by the $\operatorname{CDC}(9,16)$. One of the remarkable differences was that our rate of dyspnea and diarrhea was lower compared to the ones in the literature (9). In the study of Lu et al. the average duration of fever, which was observed as 3 days, was found to be 1.74 day in our study, which was associated with the ease of access to the healthcare services of symptomatic patients (8).

It was determined that $72.9 \%$ of the cases evaluated according to clinical disease classifications were in mild disease class. This rate was higher than $50.4 \%$, which is the mild disease rate determined according to the data of our country (7). Likewise, Dong et al. also stated the mild disease rate of confirmed cases to be $43.1 \%$ (6). The fact that the presence of asymptomatic and mild clinical disease was predominant in the age groups they included, at the age of six years and above made sense of the current clinical disease classifications with the average age in our study. The rate of asymptomatic cases confirmed in the same study was reported as $12.9 \%$, and the rate in our study was higher with $27 \%$.

In this group of patients, there is one patient who fits the multisystemic inflammatory syndrome which has been reported in the literature in April 2020 (17). That patient had poor prognostic factors such as lymphopenia, increased liver enzymes, increased inflammatory markers (C-reactive protein, ferritin), increased D-dimer, increased troponin and acute kidney injury. She died on the $20^{\text {th }}$ hour of her hospital admission.

When laboratory results were evaluated, lymphopenia was the most striking result with a rate of $37.6 \%$. In a meta-analysis compiling of 93 pediatric patients examined in seven studies, the rate of lymphopenia was reported as $41 \%$ (18). In the publication of Henry et al. where nine case reports and three studies were discussed, the rate of lymphopenia found to be $3 \%$ contradicts our study. In fact, the presence of lymphopenia has been shown to reach up to $83.2 \%$ in the studies belonging to the adult age group (19). The relationship between lymphopenia and clinical disease shown in adult studies could not be demonstrated in our study because of our cases' mild clinic $(p=0.457)$. However, when patients were grouped as under 5 and over 5 , there was a significant difference when compared to the presence of lymphopenia $(p=0.001)$.

When the asymptomatic and symptomatic groups were compared in terms of increased C-reactive protein, there was no significant difference $(p=0.768)$. The increase of procalcitonin has been detected only for one patient. In the adult age group studies, the results of these parameters associated with the severe clinical picture and poor prognosis were associated with the mild clinic and absence of concomitant bacterial infections (15). D-dimer, another factor associated with poor prognosis, was compared between two groups and was found not significant $(p=0.296)$. This situation can be explained by the fact that the clinical classification of our patients is $72.9 \%$ milder.

Direct imaging may be normal, as well as bilateral ground glass opacities at younger age and consolidations at older age. There is no clear recommendation for the pediatric age group for $C T$, which is seen as an important tool in the recognition of COVID-19 related pneumonia in the adult age group (20). Four of asymptomatic patients were imaged with thorax CT due to the need for surgical intervention and malignancy. In our study, normal imaging results were obtained in 24 (28.2\%) of 33 patients who needed CT imaging. This rate is similar to the study by Steinberger et al. evaluating radiological imaging of PCR positive patients (21). Considering patients with a confirmed diagnosis, the normality rate of imaging results was higher in the pediatric group than in the adult group (22).

In $80 \%$ of the patients, who were evaluated with existing radiology and laboratory tests, were provided with isolation at home and followed up by tele-visits. Control examinations were performed at the end of the first and the second weeks. The compatibility of our rate of hospitalization with rates reported in the literature (6-20\%) was explained by the presence of comorbid diseases (23).

Supportive treatment was administered to all patients. In addition to supportive treatment provided to each patient in need, targeted viral therapy was used in only three patients (4.5\%) in total. In the study compiled by Shekerdemian et al. this rate was reported to be $17 \%$ in the intensive care unit due to the severe clinical condition of the patients, and it was stated that other targeted antiviral treatments were needed (24). In a multicenter study, the use of 
hydroxychloroquine has been proposed in the absence of specific antiviral treatments such as remdesivir (25).

Patients who were followed up for three days without fever and did not have respiratory distress or need for oxygen were discharged. The mean duration of hospitalization was 4.8 days. Our mortality rate was $1.5 \%$.

Limitations: There are results in our study that contradict some studies and overlap with others. Our data comparison may have been insufficient since we did not have any patients with a severe or critical clinical picture. In addition, the smallness of our sample group is our most important limitation. More studies are needed to obtain exact data.

In the absence of reliable diagnostic tests and specific antiviral treatments appropriate for children, we need more virological, epidemiological, clinical, laboratory and imaging studies for understanding and managing better COVID-19 infections.

Peer Review: Externally peer-reviewed.

Ethics Committee Approval: : This study was approved by the Ethical Committee of the Istanbul University, Istanbul Faculty of Medicine (Date:15.05.2020, No: 29624016-050.99- 686).

Author Contributions: Conception/Design of Study- Ö.K.; Data Acquisition- K.A., M.S.Y., Z.B., M.Ö.; Data Analysis/Interpretation- S.H.T., A.S., S.M., A.A., Ö.K.; Drafting Manuscript- Ö.K., M.S.Y., Z.B., M.Ö., K.A.; Critical Revision of Manuscript- S.H.T., A.S., S.M., A.A.; Final Approval and Accountability- Ö.K., M.S.Y., S.H.T., K.A., Z.B., M.Ö., S.M., A.A., A.S.

Conflict of Interest: Authors declared no conflict of interest.

Financial Disclosure: Authors declared no financial support.

\section{Hakem Değerlendirmesi: Dış bağımsız.}

Etik Komite Onayı: Bu çalışma için etik komite onayı İstanbul Üniversitesi, İstanbul Tıp Fakültesi Etik Kurulu'ndan alınmıştır (Tarih:15.05.2020, Sayı: 29624016-050.99- 686).

Yazar Katkıları: Çalışma Konsepti/Tasarım- Ö.K.; Veri ToplamaK.A., M.S.Y., Z.B., M.Ö.; Veri Analizi/Yorumlama- S.H.T., A.S., S.M., A.A., Ö.K.; Yazı Taslağı- Ö.K., M.S.Y., Z.B., M.Ö., K.A.; İçeriğin Eleştirel Incelemesi- S.H.T., A.S., S.M., A.A.; Son Onay ve Sorumluluk- Ö.K., M.S.Y., S.H.T., K.A., Z.B., M.Ö., S.M., A.A., A.S.

Çıkar Çatışması: Yazarlar çıkar çatışması beyan etmemişlerdir.

Finansal Destek: Yazarlar finansal destek beyan etmemişlerdir.

\section{REFERENCES}

1. World Health Organization (WHO). Emergencies. Diseases. Coronavirus disease (COVID-19). Situation reports. Situation report-51. Available at https://www.who.int/docs/ default-source/coronaviruse/situation-reports/20200311sitrep-51-covid-19.pdf?sfvrsn=1ba62e57_10 Accessed on 5 Oct, 2020
2. World Health Organization (WHO). Emergencies. Diseases. Coronavirus disease 2019. Available at https://www.who.int/ emergencies/diseases/novel-coronavirus-2019. Accessed on 5 Oct, 2020.

3. Rodriguez-Morales AJ, Cardona-Ospina JA, GutiérrezOcampo E, Villamizar-Peña R, Holguin-Rivera Y, EscaleraAntezana JP, et al. Clinical, laboratory and imaging features of COVID-19: A systematic review and meta-analysis. Travel Med Infect Dis 2020;34:101623. [CrossRef]

4. Ludvigsson JF. Systematic review of COVID-19 in children shows milder cases and a better prognosis than adults. Acta Paediatr 2020;109(6):1088-1095. [CrossRef]

5. Halk Sağlığı Genel Müdürlüğü, COVID-19 Bilgilendirme Sayfası, COVID-19 Rehberi Çocuk Hasta Yönetimi ve Tedavi. Available at https://covid19.saglik.gov.tr/Eklenti/38596/0/ covid-19rehbericocukhastayonetimivetedavipdf.pdf Accessed on 5 Oct, 2020

6. Dong $Y$, Mo $X, H u$ Y, Qi $X$, Jiang $F$, Jiang $Z$, et al. Epidemiology of COVID-19 Among Children in China. Pediatrics 2020;145(6):e20200702. [CrossRef]

7. Lu X, Zhang L, Du H, Zhang J, Li YY, Qu J, et al. SARSCoV-2 infection in children 2020. N Engl J Med 2020;382(17):16635. [CrossRef]

8. Tezer H, Bedir Demirdağ T. Novel coronavirus disease (COVID-19) in children. Turk J Med Sci 2020;50(SI-1):592603. Published 2020 Apr 21. [CrossRef]

9. Parri $N$, Lenge $M$, Buonsenso D. Coronavirus Infection in Pediatric Emergency Departments (CONFIDENCE) Research Group. Children with Covid-19 in Pediatric Emergency Departments in Italy. N Engl J Med 2020;383(2):187-90. [CrossRef]

10. Tagarro A, Epalza C, Santos M, Sanz-Santaeufemia FJ, Otheo E, Moraleda C, et al. Screening and Severity of Coronavirus Disease 2019 (COVID-19) in Children in Madrid, Spain. JAMA Pediatr 2020 Apr 8:e201346. [CrossRef]

11. Centers for Disease Control and Prevention, Coronavirus Disease (COVID-19), Cases\&Data, MMWR COVID-19 Reports, Changing Age Distribution of the COVID-19 Pandemic_-United States, May-August 2020. Available at https://www.cdc.gov/mmwr/volumes/69/wr/pdfs/mm69 39e1-H.pdf. Accessed on 5 Oct, 2020.

12. Wu Z, McGoogan JM. Characteristics of and Important Lessons From the Coronavirus Disease 2019 (COVID-19) Outbreak in China: Summary of a Report of 72314 Cases From the Chinese Center for Disease Control and Prevention. JAMA 2020;323(13):1239-42. [CrossRef]

13. Chowell G, Abdirizak F, Lee S, Lee J, Jung E, Nishiura $H$, et al. Transmission characteristics of MERS and SARS in the healthcare setting: a comparative study. BMC Med 2015;13:210. [CrossRef]

14. Zhang B, Liu S, Zhang J, Xiao J, Zhu S, Dong Y, et al. Children hospitalized for coronavirus disease 2019 (COVID-19): A multicenter retrospective descriptive study. J Infect 2020;81(2):e74-5. [CrossRef]

15. Zhou F, Yu T, Du R, Fan G, Liu Y, Liu Z, et al. Clinical course and risk factors for mortality of adult inpatients with COVID-19 in Wuhan, China: a retrospective cohort study. Lancet 2020;395(10229):1054-62. [CrossRef] 
16. CDC COVID-19 Response Team. Preliminary Estimates of the Prevalence of Selected Underlying Health Conditions Among Patients with Coronavirus Disease 2019 - United States, February 12-March 28, 2020. MMWR Morb Mortal Wkly Rep 2020;69(13):382-386. [CrossRef]

17. Deza Leon MP, Redzepi A, McGrath E, Abdel-Haq N, Shawaqfeh A, Sethuraman U, et al. COVID-19 Associated Pediatric Multi-System Inflammatory Syndrome. J Pediatric Infect Dis Soc 2020;9(3):407-8. [CrossRef]

18. Chang TH, Wu JL, Chang LY. Clinical characteristics and diagnostic challenges of pediatric COVID-19: A systematic review and meta-analysis. J Formos Med Assoc 2020;119(5):982-9. [CrossRef]

19. Guan WJ, Ni ZY, Hu Y, Liang WH, Ou CQ, He JX, et al. China Medical Treatment Expert Group for Covid-19. Clinical Characteristics of Coronavirus Disease 2019 in China. N Engl J Med 2020;382(18):1708-1720. [CrossRef]

20. Ma H, Hu J, Tian J, Zhou X, Li H, Laws MT, et al. A singlecenter, retrospective study of COVID-19 features in children: a descriptive investigation. BMC Med 2020;18(1):123. Published 2020 May 6. [CrossRef]
21. Steinberger $S$, Lin $B$, Bernheim A, Chung $M$, Gao $Y$, Xie $Z$, et al. CT Features of Coronavirus Disease (COVID-19) in 30 Pediatric Patients. AJR Am J Roentgenol 2020;215(6):130311. [CrossRef]

22. Chen A, Huang J, Liao Y, Liu Z, Chen D, Yang C, et al. Differences in clinical and imaging presentation of pediatric patients witf COVID-19 in comparison with adults. Radiol Cardiothrac Imaging 2020;2(2):e200117. [CrossRef]

23. Chen ZM, Fu JF, Shu Q, Chen YH, Hua CZ, Li FB, et al. Diagnosis and treatment recommendations for pediatric respiratory infection caused by the 2019 novel coronavirus. World J Pediatr 2020;16(3):240-6. [CrossRef]

24. Shekerdemian LS, Mahmood NR, Wolfe KK, Riggs BJ, Ross CE, McKiernan CA, et al. Characteristics and Outcomes of Children With Coronavirus Disease 2019 (COVID-19) Infection Admitted to US and Canadian Pediatric Intensive Care Units. JAMA Pediatr 2020;174(9):868-73. [CrossRef]

25. Chiotos K, Hayes M, Kimberlin DW, Jones SB, James SH, Pinninti SG, et al. Multicenter initial guidance on use of antivirals for children with coronavirus disease 2019/severe acute respiratory syndrome coronavirus 2. J Pediatric Infect Dis Soc 2020;9(6):701-15. [CrossRef] 